Whigham, S. and May, A. () 'Sport for Yes'? The role of sporting issues in pro-independence political discourse during the Scottish independence referendum campaign', International Journal of Sport Policy and Politics

DOI:

This document is the authors' Accepted Manuscript.

License: https://creativecommons.org/licenses/by-nc-nd/4.0

Available from RADAR: https://radar.brookes.ac.uk/radar/items/314eec28-6050-4c41-8027-9af8db633566/1/

Copyright $(\subseteq$ and Moral Rights are retained by the author(s) and/ or other copyright owners unless otherwise waved in a license stated or linked to above. A copy can be downloaded for personal non-commercial research or study, without prior permission or charge. This item cannot be reproduced or quoted extensively from without first obtaining permission in writing from the copyright holder(s). The content must not be changed in any way or sold commercially in any format or medium without the formal permission of the copyright holders. 


\title{
'Sport for Yes'? The role of sporting issues in pro-independence political discourse during the Scottish independence referendum campaign
}

\author{
Stuart Whigham ${ }^{\mathrm{a}}$ and Anthony May ${ }^{\mathrm{b}}$ \\ a Department of Sport and Health Sciences, Oxford Brookes University, \\ UK; ${ }^{b}$ Coventry Business School, Coventry University, UK
}

\section{Abstract}

This article critically considers the extent to which sporting issues were harnessed by pro-independence political campaigners during the Scottish independence referendum campaign. Developments such as the inclusion of sport within the Scottish Government's White Paper on Scottish independence, the establishment of the 'Working Group on Scottish Sport' and the establishment of the 'Sport for Yes' campaign group demonstrate the harnessing of sporting issues as an additional, if somewhat peripheral, debate point in the referendum campaigns (Lafferty 2014, Scottish Government 2013, Working Group on Scottish Sport and Scottish Government 2013, 2014). The latter of these developments, the establishment of the 'Sport for Yes' campaign group, is of particular interest, offering evidence of the explicit political mobilisation of past and present athletes in support of the 'Yes Scotland' pro-independence campaign. The use of sport within pro-independence political discourse is therefore scrutinised, drawing upon the principles of critical discourse analysis to explore the ideological assumptions underpinning the discursive representation of sport in relation to Scottish independence. 
Key words: political discourse; Scottish nationalism; sport; cultural nationalism; political communication

\section{Introduction}

Smith (1991, p. 9) argues that a nation can be defined as 'a definite social space [and] a fairly well demarcated and bounded territory, with which the members identify and to which they feel they belong'. Although Scotland has a clearly demarcated border, it is also a constituent nation of the United Kingdom (UK). This means that ideas about belonging and national identity in Scotland are strongly contested. Scottish nationalism is at its strongest in centuries, and the Scottish National Party (SNP) are the ruling party in the Scottish Parliament. At the 2015 UK general election, 56 out of 59 members returned to the UK Parliament at Westminster were SNP candidates (BBC 2015). Politically, advocates and independence are in a very strong position in Scotland.

This is the case despite the fact that a referendum on Scottish independence held on 18th September 2014 resulted in $55.3 \%$ of the Scottish electorate voting "No" to the idea of Scotland becoming an independent nation (BBC 2014). Both the "Yes" and "No" campaigns utilised ideas about nationalism and belonging, and broadly speaking, portrayed Scotland either in terms of its potential as a separate nation or in terms of its perceived position of strength within the UK. Competing identities were expressed on a whole gamut of different issues; many of these were political and legal, but cultural issues also played a key role within the two campaigns. 
There are many different ways in which national identity can be expressed, and as Smith (2010, p. 81) argues:

Nationalism cannot be confined within the political, or any other domain, and to oppose "politics" to "culture" [...] does not help to advance understanding of complex phenomena such as nations and nationalism.

Culture and politics are closely related and the interplay between them plays a key part in producing the identity of any nation. Nationalism is not just a political ideology; in order to understand the politics of a nation, it is essential to also understand that nation's culture. The aim of this article is to examine how ideas about a particular form of culture, in this case sport, were expressed during the campaigning that preceded the referendum on Scottish independence which took place on 18th September 2014.

\section{Theories of national identity and cultural nationalism in Scotland}

One of the most significant theorists of nationalism, John Hutchinson (2001), discusses the existence of political and cultural forms of nationalism, and outlines the key differences between them. In support of his assertion that nationalism can be understood as a popular movement, Hutchinson (2001, p. 78) argues that while political nationalism consists of attempts to advance the claims of a nation to sovereignty from within the politico-legal system, cultural nationalism 'can create a counter-cultural centre against the state' by mobilising non-state movements in support of the nationalist project (Hutchison, 2001, p. 78).

In separating political and cultural nationalism into different spheres, Hutchinson does not argue that cultural nationalists are apolitical. Rather, it is the 
case that cultural nationalism is political in character, but is not solely restricted to politico-legal mechanisms. Broadly speaking, cultural nationalism is the expression of nationalist ideals outside the direct political sphere and the idea that cultural nationalism is politically significant, but not confined to the political arena, is significant. Hutchinson (2001, p.75) argues that some theorists (chiefly Gellner, and also Breuilly) tend to present national cultures as homogenous because they see them as being under the control of the state; this approach 'neglects the persistence of cultural divisions within many nations whose recurring contestations offer rival directions as to how the community should develop'. Clearly, in the case of Scotland, such contestations are prominent and play an important part in the development of identity.

Similarly to Hutchinson, Smith (2010, p.3 7) argues that for nationalisms to succeed and take root within any given unit of population, 'the cultural nation must become the political nation, with public culture the mould and measure of society and polity'. Smith (2010) also separates cultural nationalism from political nationalism and suggests that the initial concern of cultural nationalists is with moral and social rather than territorial issues. However, this changes over time, according to Smith (2010, p. 81), so that 'political and cultural forms of nationalism often succeed one another'. In essence, cultural nationalists mould the character of the nation, and political nationalists use this material to build their claims to sovereignty. This article will assess the extent to which cultural nationalists in Scotland developed ideas about identity through sport during pre-referendum campaigning. It will also assess the ways that political nationalists attempted to utilise arguments about sport and the material developed by cultural nationalists, creating a detailed picture of both forms of nationalism in the process. 
As Pittock (2008) suggests, there is a widely held idea that in the last four decades Scotland has become marginalised in the United Kingdom, and has become increasingly culturally different as a consequence. Nairn (1977) was in the vanguard of this idea, but it has been taken up by many others since. To give one example of many possible, Dixon (1996, p. 18) has argued that in the contemporary era Scotland has a 'coherent [and] alternative vision of cultural production' to the rest of the United Kingdom. Similarly, writing about contemporary Scottish culture, Pittock (2008, p. 123) argues that 'one of the features of the creation of a Scottish cultural agenda after 1979 was a determination to rid the country of the historical clichés, inferiorism and misunderstandings which it was believed by some had held Scotland back from devolution' in 1979. The extent to which sport can be described as part of the separate Scottish cultural agenda identified by Pittock and Dixon will be examined in the sections that follow.

\section{Sport, nationalism and political nationalism in 'submerged nations'}

Sport is frequently held to be an important domain for the expression of national identity in the contemporary era. For example, in his extended work on the nature of 'everyday nationalism' in contemporary society, Tim Edensor argues that a stance which prioritises nationalism 'from below' avoids the problems which are engrained in the predominant paradigms in the study of nationalism, which are "seriously distorted in their consideration of 'high', 'official' and 'traditional' culture to the exclusion of popular and everyday cultural expression" $(2002$, p. 2). With regards to sport, Edensor therefore contents that "[p]robably the most currently powerful form of popular national performance is that found in sport... these 
everyday and spectacular contexts provide one of the most popular ways in which national identity is grounded" (2002, p. 78). Although it is therefore often accepted that sport can play a central role in contemporary expressions of nationalist feelings, such feelings tend to be limited to the sporting domain and seldom correlate to expressions of political nationalism (Bairner 1996, 2001; Kellas 1998). Furthermore, an oft-cited argument regarding the necessity of avoiding the politicisation of sport has been continuously perpetuated by some in both the public and academic domains, despite continued academic critique of such an argument (Allison 1986, Maguire et al. 2002). To this end, Allison (1993, p. 5) argues 'sport has a complex and important interaction with nationality and the phenomenon of nationalism', emphasising the continued importance of ongoing academic scrutiny of the relationship between sport, nationalism and politics.

Although most analyses of sport and political nationalism have concentrated on examples of political exploitation of sport by existing sovereign states (Maguire et al. 2002), a number of academics have also examined examples of 'submerged nations' within existing state formations, such as the case of Scotland. For example, analyses of the Catalan and Basque regions of Spain have highlighted the importance of FC Barcelona and Athletic Bilbao (respectively) for the expression of regional and ethnic identities for the population of these regions (Conversi 2000, Duke and Crolley 1996, Goig 2008, Guibernau 2000, Maguire et al. 2002, Shobe 2008a, 2008b; Vaczi, 2015a, 2015b, 2017). For example, Vaczi’s (2015a) extended analysis of the nature of Basque nationalism in the Spanish context is based on the contention that "Basque soccer fandom in Spain reflects the political anthropology of a nation without a state, one that is chronically divided within, and antagonized without as it struggles to resolve its political impasses" (2015, p. 10). Both the Basque and 
Catalan regions have witnessed the development of political nationalism which seeks to increase the democratic power of their respective regional parliaments, either in the form of increased autonomy within a federalised Spanish state or as an independent and sovereign nation-state (Duke and Crolley 1996, Hargreaves 2000).

For example, Hargreaves' (2000) extended analysis of the 1992 Olympic Games hosted in Barcelona argues that the event represented a political threat for political actors on different sides of the constitutional debate in Catalonia. This in turn resulted in contrasting movements supporting the 'Catalanisation' or 'Espanolisation' of the Games in terms of its symbolism, organisation and the use of the Catalan language throughout the event. This echoes the earlier arguments of Blain, Boyle and O'Donnell (1993), whose analysis identified a 'unitary discourse' which emphasised the "unity of the Spanish nation" (1993, p. 163), a 'disjunctive discourse' which emphasised the autonomy of Catalonia, and a middle-ground 'differential discourse' which possessed an ability to acknowledge the importance of peripheral regions such as Catalonia whilst still emphasising the role of central government.

Whilst the ongoing constitutional debate in Catalonia continues to this date, with these competing discourses remaining prevalent, the political ramifications of the 1992 Barcelona Games are partially analogous to the case of Scotland in 2014, given the hosting of the Commonwealth Games in Glasgow in 2014; attention will therefore be given now to the specific case of Scotland, and the relationship between sport and Scottish political nationalism.

\section{Sport and political nationalism in Scotland}


Bairner's (1996) arguments on the link between sport and Scottish national identity suggest that sport represents the most popular means for the expression of national identity in Scotland. However, in order to critically reflect upon the political exploitation of sport within Scottish political nationalist movements, it is firstly necessary to look outside of sports argued to have Scottish 'origins' (whether legitimate or dubious), such as golf, shinty and the Highland Games, to consider this relationship. For example, Maclennan's (2000) analysis of the sport of shinty argues that its legitimate, but often derided, claim as Scotland's national sport lies in its strong links with indigenous Gaelic heritage. Maclennan highlights the frequentlydrawn links with the Irish sport of hurling; however, such a contrast serves to illustrate the declining popularity of shinty in comparison to its Irish counterpart, with the sport of shinty requiring central intervention and funding to support its continuation in the post-1945 period.

This lies in stark contrast to the partially analogous case of the Republic of Ireland, and the relationship between sport and Irish political nationalism. For example, the relative unpopularity of sports with distinct Scottish origins lies in contrast to the Irish context, for whom sports such as hurling and Gaelic football have continued to act as important leisure activities in their new setting (Darby 2009, Darby and Hassan 2008). This failure has been attributed to the lack of a Scottish equivalent to the Gaelic Athletic Association (GAA) (Bairner and Whigham 2014, Bradley 1998, 2007, Holt 1989, Jarvie 1993, Jarvie and Walker 1994), with Jarvie and Walker arguing that during the period of the establishment of the GAA 'Scotland... did not want to break out of the Act of Union and in this fact alone, lies one of the many reasons why a similar organisation to the Gaelic Athletic Association did not develop in Scotland' (1994, p. 6). Harvie (1994) draws similar 
conclusions regarding the lack of a Scottish equivalent to the GAA, arguing that the lack of political organisation and support for Scottish sports such as shinty denied them the impetus required to gain in popularity and importance vis-à-vis other popular sports such as football or rugby union.

In this light, Bairner (1996) argues that team sports such as football and rugby constitute an additional form of distinct civil society in Scotland, acting in much the same way as the 'holy trinity' of independent civic institutions found in the Scottish educational, legal and Church systems (McCrone 1992, Pittock 2012). The existence of independent Scottish representative teams in international football and rugby competition, for example, reinforces the idea of a distinct Scottish nation (Allison, 2000, Bairner 1994, 1996, 2000, Blain et al. 1993, Brand 1978, Duke and Crolley 1996, Jarvie and Walker 1994, Moorhouse 1987, Polley 2004), all the more so given the fact that no nations outside of the UK are afforded this opportunity where they are not recognised as sovereign states. Bairner (2001) later highlighted that this anomaly in the international sporting system means that notions of Scottish nationhood and a congruent distinct national identity are not in doubt for Scots, despite their acceptance that the Scottish nation does not possess a truly independent or sovereign status. Furthermore, the privileged existence of separate national teams from all four 'Home Nations' within the UK has led some academics to argue that comparative 'submerged nations', such as Catalonia and the Basque region, have sought to achieve a similar status for their own 'nations' in past attempts to establish independent sporting teams (Maguire et al. 2002; Vaczi 2015a, 2015b, 2017).

Although individual sports tend to carry weaker associations with nationalist sentiment (Whigham 2014), the case of Andy Murray exemplifies the potential for the intertwining of individual athletes and political controversy. Murray's victories 
at the 2012 London Olympics, 2012 US Open and 2013 Wimbledon competitions led to accusations of political exploitation of his successes by politicians such as Alex Salmond, who emphasised Murray's 'Scottishness' following his 2012 successes and controversially waved a Scottish saltire flag at the Wimbledon final, and David Cameron, who emphasised Murray's 'Britishness' following his 2012 Olympic gold medal (Channel 4 News 2012). Murray himself expressed his dissatisfaction at the political exploitation of his successes when question on his opinion on Alex Salmond, stating that Salmond 'seemed perfectly nice to me, but I didn't like it when he got the Scottish flag up at Wimbledon' (Shipman 2014).

Despite examples such as these where Scottish sport and politics have mixed, and the importance of sport for fostering and maintaining Scottish national identity, most past analyses of Scottish sport have argued that there is not necessarily a direct correlation between sporting nationalism and political nationalism for the majority of Scots (Bairner 1994, 1996, 2001, Jarvie 1993, Jarvie and Walker 1994, Kelly 2007). These arguments have often highlighted the relative fallacy of claims regarding the impact of sporting victory and defeat on political events, such as the suggestion that the failed campaign of the Scottish football team in the 1978 FIFA World Cup in Argentina may have influenced the result of the 1979 referendum on Scottish devolution (Bairner 1994, Boyle and Haynes 2009, Jarvie 1993, Jarvie and Walker 1994, Kowalski 2004). The oft-quoted remark by the outgoing SNP MP for Govan Jim Sillars following his defeat in the 1992 general election in which he denounced his fellow Scots as '90-minute patriots' has been used to symbolise the lack of synergy between sportive and political nationalism in Scotland (Bairner 1996, Kowalski 2004). 
However, given that the majority of the aforementioned analyses of the relationship between sporting and political nationalism were written during the predevolution era of the 1990s or in the immediate aftermath of the re-establishment of the Scottish Parliament in the early 2000s, the shifting political context in Scotland which has saw the rise of the nationalist SNP to government suggests that revisiting this relationship at the present time is beneficial. Furthermore, in contrast to his predecessor, Alex Salmond argued that the Scotland's successful qualification for the 1998 World Cup in France helped to boost the 'Yes' vote in the 1999 referendum (Kowalski, 2004). For Jarvie and Walker (1994), the 'substitute thesis' adopted by Sillars which views sporting nationalism as a direct replacement for sporting nationalism is 'at once too static and too one-dimensional to help us explain the way sport has reflected Scottish life in its different political, social and cultural manifestations' $(1994$, p. 2). In contrast, Bairner $(1994,1996)$ lends some support to the '90-minute patriot' thesis, arguing that it may be safer for Scots to be display sporting nationalism rather than political nationalism given the internal divisions within Scotland caused by religious and regional identity. For Bairner, these fissures prevent the possibility of achieving any semblance of a singular Scottish identity, whether in a cultural, political or sporting sense, highlighting the complexity of the task of understanding Scottish national identity.

\section{Sport, critical discourse analysis and political discourse analysis}

Given the complexity of the historic relationship between sport and Scottish political nationalism, the case of the 2014 Scottish independence referendum provides an opportunity for a contemporary revisiting of this relationship. Attention 
will therefore now turn to an analysis of the use of sport within the official independence referendum campaign of pro-independence parties and organisations, namely the SNP and 'Yes Scotland' campaign group. In order to critically examine the nature of contemporary political rhetoric regarding sport and Scottish nationalism, this article draws upon the principles of critical discourse analysis (CDA), and, more specifically, the analytical framework proposed by Norman Fairclough and Isabela Fairclough (2012) for scrutinising political discourse.

CDA, as one of many forms of textual analysis, places a significant emphasis on understanding the wider social and political context within which a given text is located, scrutinising the influence of external factors on the character and form of the text (Titscher et al. 2000, Fairclough 2015). Fairclough and Wodak's (1997, p. 258) collaborative work demonstrates their shared understanding of CDA as viewing discourse as a form of 'social practice', implying 'a dialectical relationship between a particular discursive event and the situation(s), institution(s) and social structure(s) which frame it'. Although CDA as a methodological approach has been used in a vast array of contexts, its emphasis on scrutinising the power relations and social context within which a specific example of discourse is situated has led to its frequent use within the field of politics. Indeed, the work of Norman Fairclough has predominantly focused on discourse within the domain of politics, noting the importance of discourse for political actors to gain support:

In politics, each opposing party or political force tries to win general acceptance for its own discourse type as the preferred and ultimately the 'natural' one for talking and writing about the state, government, forms of political action, and all aspects of politics. (Fairclough 2015, p. 112) 
The current article draws upon one specific analytical framework for political discourse, namely that proposed by Isabela Fairclough and Norman Fairclough (2012). This framework represents the most recent substantive development of Norman Fairclough's previous work situated within the wider school of CDA. Fairclough and Fairclough's (2012) analytical framework aims to build upon the authors' earlier work in the fields of CDA and political discourse analysis, with its specific emphasis on the integration of argumentation theory distinguishing the model from others in this analytical field. The authors contend that the proposed framework 'views political discourse as primarily a form of argumentation, and as involving more specifically practical argumentation, argumentation for or against particular ways of acting, argumentation that can ground decision' (2012, p. 1; original emphasis).

Furthermore, the framework distinguishes between different constitutive elements of practical arguments found within forms of political discourse. The authors identify 'narratives', 'mental conceptions' and 'imaginaries' as important aspects of the arguments found within political discourse:

...narratives of the [2008 global financial] crisis are incorporated within what we will call the 'circumstantial premises' of practical arguments (premises which represent the context of action); 'imaginaries' for possible and desirable states of affairs are incorporated in our account within the 'goal premises'. (Fairclough and Fairclough, 2012; p. 4)

Greater emphasis is placed on the role of the 'imaginary' within the analytical framework, with Fairclough and Fairclough stating that only 'imaginaries' are a form of practical argumentation for future action given that 'narratives' simply 
act as representations of past or present circumstances. The 'performative power' of the imaginary is argued to lie in its emphasis on the 'goal premise' of an argument, with Fairclough and Fairclough arguing that to successfully achieve consensus for political action an arguer 'represents the 'imaginary' as 'actual' and he attempts to get it collectively recognized as a factual representation." (2012, p. 108).

As part of their analytical framework, Fairclough and Fairclough identify a number of structured features which commonly emerge as part of effective political argumentation:

Figure 1. Diagrammatic representation of the structure of practical reasoning (Fairclough and Fairclough 2012, p. 48)

Within this conceptualisation of practical argumentation, a claim for a specific course of political 'action' is primarily driven by the normative political and ideological 'values' of a political actor or group, with these 'values' in turn shaping the particular political 'goal' of the respective actor or group. These 'goal premises' are represented in discursive form as an 'imaginary' of a future state of affairs. The course of action argued is therefore viewed as a 'means-goal', with the specific action representing a means to an end for achieving a political imaginary. Although secondary in terms of their importance within this framework, the 'circumstances' represented within a particular argument are still conceptualised as partially influential in justifying a course of action. The 'circumstantial' premises, however, are suggested to be non-argumentative in nature by Fairclough and Fairclough, with the narratives and other discursive genres used by a political actor to simply contextualise the current state of affairs. 
It is these core analytical categories that will be applied in the forthcoming examination of political discourse relating to sport from groups, organisations and actors affiliated to the official pro-independence campaign in the Scottish independence referendum. Specifically, the forthcoming discussion will examine campaign manifesto documents, press releases and policy reports from the Scottish National Party (including publications from the SNP-led Scottish Government currently in power in the devolved Scottish Parliament) and the 'Yes Scotland' campaign group, given that these constituted two of the most influential proindependence political organisations in the official referendum campaign. Whilst this methodological approach is therefore limited to an analysis of the nature of the emergent discursive patterns in its own, rather than a exploring the impact of this political discourse on the voting intentions of the Scottish electorate in terms of cause-and-effect, the forthcoming discussion facilitates an opportunity to explore the ideological assumptions which underpin the framing of sport by pro-independence political campaigners.

The role of sport in pro-independence discourse in Scotland - illustrating ideological 'values' and constrained 'circumstances'

The forthcoming discussion narrows its focus specifically to a purposive sample of documents and publications which explicitly discuss the relationship between Scottish independence and sporting issues, thus producing a manageable range of data sources given the relatively low priority of sporting issues within the pro-independence referendum campaign. A total of 25 documents were analysed, constituted of 5 manifesto documents, 18 press releases and 2 policy reports. 
Figure 2 provides a diagrammatic representation of Scottish pro-independence campaign political discourse regarding sporting issues, applying the Fairclough and Fairclough (2012) framework's core analytical categories of 'values', 'goals', 'circumstances' and 'claim for action' in order to analyse the central themes which emerged from this data sample. The diagram can thus be viewed as an aggregation of a range of publications from various political actors from the pro-independence campaign. However, this does not necessarily indicate that these publications constitute a cohesive strategy regarding sporting policy and issues given the somewhat disparate nature of the sources in terms of their authorship and publication date, especially so given the presence of contrasting political parties, namely the SNP and the Scottish Green Party, with their varying political ideologies.

Figure 2. Diagrammatic representation of Scottish pro-independence campaign political discourse regarding sporting issues

Considering each of the core analytical categories in turn, an appropriate startpoint is to examine the discursive construction of the past and present 'circumstances' of Scottish sport. The two quotes included in Figure 2 indicate the emphasis placed in pro-independence political discourse regarding the centrality and importance of sport in Scottish society. For example, the 'Scotland's Future' White Paper (Scottish Government 2013), the official 'blueprint' for Scottish independence, argues that 'Scots are passionate about sport and our country has a long and proud sporting tradition' (p. 176), and the final report of the Working Group on Scottish Sport (WGSS) (WGSS \& Scottish Government 2014) stating that '[s]port is a part of the fabric of Scottish society' (p. 3). Juxtaposed against this construction of a sport-loving Scottish nation is a narrative of a constrained Scottish 
sporting system, with WGSS final report highlighting: (1) the lack of independent Scottish representation in certain sporting systems, particularly the Olympics and Paralympics; (2) the declining levels of sports participation in Scotland; and (3) the varying existing levels of autonomy for Scottish sporting organisation within the UK sporting system (WGSS and Scottish Government 2014).

These arguments regarding the constrained nature of Scottish sport are further underlined by the use of the 2014 Commonwealth Games and Ryder Cup as an argument for a 'Yes' vote by the SNP, given that this would avoid the current circumstances whereby the Scottish tourism industry's attempts to use the Games are hampered by the 'Tourism Tax' of Air Passenger Duty if responsibility was transferred to an independent Scotland (SNP 2014a, 2014b). This aspect of the discursive construction of Scotland's 'circumstances' illustrates the frequent emphasis on the Scottish 'democratic deficit', with Scotland portrayed as a submerged nation which lacks the political and fiscal powers to flourish. This provides further justification for arguments regarding the centrality of such arguments in the SNP's political strategy (Casanas Adam, 2014; Dalle Mulle, 2016; Keating, 2012; Mycock, 2012).

Having considered the rhetoric of the constrained 'circumstances' of Scottish sport prevalent in pro-independence political discourse, the 'values' which underpin the pro-independence campaign discourse regarding sporting issues are unsurprisingly based on a fundamental belief in the benefits of gaining sovereign statehood for Scotland. The White Paper (Scottish Government 2013) best epitomises this foundational belief in the importance of political self-determination for Scotland, with the document's preface attributed to ex-First Minister Alex Salmond stating: 
At its heart independence is not about this Government or any political party. It is about a fundamental democratic choice for the people of Scotland. It is about the power to choose who we should be governed by and the power to build a country that reflects our priorities as a society and our values as a people. I believe in independence because I believe it will be better for all of us if decisions about Scotland are taken by the people who care most about Scotland - the people who live and work here. (Scottish Government 2013; p. viii-ix)

This core message regarding independence as a means to ensuring that 'Scotland's future is in Scotland's hands' is a consistent theme within the White Paper, invoking language regarding the importance of political self-determination for nations as the central aim of the contemporary Scottish independence movement. This discursive strategy demonstrates clear synergies with adherents of 'ideological' modernist theorisations of nationalism (Smith 2010), with the work of Kedourie (1960) exemplifying this belief in the ideological power of nationalist doctrine which emphasises that the nation-state is the medium through which individuals can achieve sovereignty and self-determination for the social collective they align with emotionally, in this case Scotland.

Furthermore, the emphasis in this extract from the White Paper's preface on the identification of "the people who live and work here" (Scottish Government 2013, p. ix) as the people of Scotland signposts the eminence of 'civic nationalism' (Kohn 1944) within the discourse of contemporary Scottish political discourse. The emphasis on 'civic nationalism' is particularly evident within the section of the White Paper which specifically discusses the Scottish Government's proposals for Scottish citizenship rights in the event of a Yes vote: 
Figure 3. Proposals for Scottish citizenship rights in an independent Scotland (Scottish Government 2013, p. 273)

Leith and Soule's (2011) past analysis of discourse contained within manifestos of mainstream Scottish political parties offered a similar consideration of the emphasis placed on 'civic' and 'non-civic' (or 'ethnic' using Kohn's (1944) terminology) nationalism, drawing similar conclusions regarding the aforementioned emphasis on the civic nature of Scottish nationalism and Scottish society. Furthermore, these manifestos often make explicit reference to Scotland's diversity and its welcoming of ethnic minorities to Scottish society within pro-independence, 'large 'N'" nationalism (Leith and Soule 2011); these findings are clearly evident in the 'values' of current official political discourse considered in this article. This emphasis on 'civic nationalism' is unsurprising given the political ramifications of any associations with discriminatory or xenophobic feeling within the Scottish nationalist movement. Nonetheless, certain elements of 'non-civic' nationalism remain evident within Scottish political discourse, with emphasis often placed on the importance of landscape and language as a source of pride for the Scottish nation (Leith and Soule 2011; Kiely, Bechhofer and McCrone 2005; McCrone and Bechhofer, 2010; Mycock 2012).

The final aspect of the 'values' outlined in Figure 2 relates to the ideological beliefs regarding the political importance of sport within pro-independence political discourse. The most common theme emerging in relation to sport is an emphasis on the use of sport as a tool of economic and social development, evident in key publications such as the White Paper, the WGSS final report, and press releases from the official 'Sport for Yes' campaign group (Lafferty 2014; see also 
https://twitter.com/SportforYes). For example, the White Paper outlines the SNP-led Scottish Government's vision for sport as follows:

We believe that by looking at physical activity and sport together will we harness that passion and tradition to make positive changes in our country improving health, reducing anti-social behaviour and making our society fairer. (Scottish Government 2013, p. 176)

Similar comments are offered in the final report of the WGSS:

...we should not underestimate the positive role that grassroots sports and physical activity in general can play in the health and wellbeing of Scotland and the national psyche. (WGSS and Scottish Government 2014, p. 2)

These statements clearly prioritise the utility of sport as a vehicle for social development primarily with their emphasis on the improvement of health, wellbeing and the 'national psyche', as well as the tackling of anti-social behaviour. Furthermore, these goals can equally be viewed as an attempt to use sport for instrumental means regarding economic development, given that improving health and wellbeing has a knock-on effect on economic productivity levels and the reduction of long-term NHS funding costs (McCartney et al. 2010, McCartney et al. 2012). In particular, this emphasis on economic considerations aligns with the party's ideological 'values', especially their attempts to project a position which is pro-business and focused on Scottish economic growth (Lynch, 2009; Tomlinson, 2014). 
The role of sport in pro-independence discourse in Scotland - scoring the 'goal' of independence?

These foundational 'values' regarding the use of sport as for economic and social development are thus reflected in the 'goal' of pro-independence political discourse regarding sport, which centres on the identification of the numerous opportunities to improve Scottish sport in the context of an independent Scotland. Indeed, the specific remit of the WGSS was identified to be the consideration of 'how sport can develop and take advantage of the opportunities presented by independence' (Scottish Government 2013, p.179) and 'to build upon the independence White Paper and further inform the referendum debate as it relates to sport; and to inform the policy and strategy for sport and physical activity of the current and future Scottish Governments and the sporting bodies' (WGSS and Scottish Government 2014, p. 8).

Both the White Paper and the WGSS final report reinforce this central 'goal' by outlining the opportunities for the improvement of health and well-being, the enhancement Scotland's sporting reputation, the reduction of anti-social behaviour, the creation of a fairer society and the creation of a more efficient sporting framework (Scottish Government 2013, WGSS \& Scottish Government 2014). However, given that the WGSS final report acknowledges the fact that sport is a fully-devolved policy area controlled by the Scottish Parliament, a coherent argument regarding exactly why independence is required to enact these specific goals is not explicitly forwarded in pro-independence political discourse. Whilst the White Paper clearly argues that in 'an independent Scotland, we will build on this record [of SNP-led sports policy successes] to grow a world class sporting system at 
all levels, with real strength in schools, clubs and high performance sport' (Scottish Government 2013, p. 179), the necessity for Scottish independence in order to realise this rhetoric is unclear. This can be argued to be reflective of accusations made by pro-union parties in Scottish politics about the perpetuation of a 'grievance culture' by the SNP government which blames Westminster for budgetary cuts, despite possessing the political means to counter their impact (Lecours, 2012; Leith and Soule, 2011; Newby, 2009; Pittock, 2008).

In contrast, the arguments forwarded regarding the 'goal' of achieving independent Scottish representation in Olympic, Paralympic and international sporting federations are more coherent. To this end, the 'Yes Scotland' campaign launched the 'Sport for Yes' campaign group to promote the potential benefits of independence for Scottish sport, with endorsements for the group coming from athletes or players, such as Michael Stewart (football), Alex Arthur (boxing), Connie Ramsay (judo) and Samera Ashraf (kickboxing and karate), cited in the 'Sport for Yes' campaign launch event (Lafferty 2014). The White Paper highlights that interim statement of the WGSS released in November 2013 (WGSS and Scottish Government 2013) which specifically considers the likelihood of Scotland achieving accreditation from the IOC and IPC in sufficient time for the Rio 2016 Olympics, with interim statement arguing:

At a very practical level, given the experience of other newly independent states, we see no reason why securing National Olympic and Paralympic Committee status should not be a relatively straightforward process for an independent Scotland. However, we recognise that the final decision making powers and the timescales involved are a matter for the relevant international bodies. (WGSS and Scottish Government 2013, p.2) 
This caveated statement regarding the likelihood of smooth accreditation of a Scottish Olympic and Paralympic representative team, adding to the pre-existing Scottish representative teams found in other sporting competitions, thus allowed the White Paper to argue that:

Independence will mean that more Scottish sportswomen and sportsmen will have the opportunity to compete at the highest level of international competition. It will also mean that the key decisions on athlete development will be taken in Scotland with the needs of the athlete at the centre. This will help many more of our sports-people reach their full potential. (Scottish Government 2013, p. 179)

Scottish independence is therefore framed as a means to expanding the proportion and number of Scottish sportspeople who will be able to compete in sporting competitions where they have previously been part of a combined British representative team, thus potentially echoing the size of Scottish representatives at events such as the Commonwealth Games where Scotland has an independent squad:

The group has also suggested ways to build on the support already in place for international athletes - independence will create better opportunities for more athletes, giving more Scottish sportsmen and sportswomen the chance to compete at the highest level of international competition. (Scottish Government, 2014)

There is therefore a degree of validity to the White Paper's claims in this regard in a practical sense. However, it can also be argued that this example is also 
used as another analogy for portraying Scotland as a constrained, with the prospect of enhanced Scottish representation in the sporting domain analogous to the SNP's political strategy of gaining political and economic self-determination for representation in the global economy (Casanas Adam, 2014; Dalle Mulle, 2016; Keating, 2012; Mycock, 2012).

Indeed, it can be argued that establishment of the WGSS itself can viewed as the SNP-led Scottish Government main drive towards using sport as means to supporting their drive for a 'Yes' vote in the referendum. Given that the 'meansgoal' of pro-independence discourse highlighted in Figure 2 is to encourage the Scottish electorate to vote 'Yes', thus achieving the ultimate 'goal' of achieving Scottish independence, the establishment of the WGSS can be viewed as a pro-active step to both emphasise the potential benefits of independence for Scottish sport whilst simultaneously negating concerns regarding its potential risks. Therefore the ultimate 'claim for action' is for the electorate to take the action of voting 'Yes' to Scottish independence, thus allowing the proposals of the WGSS final report and the White Paper to be implemented.

The specific 'claims for action' with regard to future sports policy in an independent contained with the WGSS final report and the White Paper clearly seek to address the problems highlighted in pro-independence discourse regarding the past and present 'circumstances' of Scottish sport, with particular emphasis on a more holistic approach to sport and physical activity which will allow "a world class sporting system at all levels, with real strength in schools, clubs and high performance sport" (Scottish Government 2013, p. 179). Emphasis is also placed on a streamlining with regards to the governance of elite sporting organisations in an independent Scotland, with recommendations regarding the creation of a single body 
to act as the National Olympic, National Paralympic and Commonwealth Games Committees as part of reforms in time for Rio 2016 (WGSS and Scottish Government 2014). The proposed future use of sporting events as a catalyst for developing Scotland's international image and reputation would also act as a continuation of the current 'values' of using sport as a tool for economic and social development, given the opportunities for economic, tourism, sporting and health legacies emphasised by the incumbent SNP-led Scottish Government (Scottish Government, 2015).

\section{Conclusions}

Given the extended nature of the Scottish independence referendum campaign and the exhaustive list of issues which became politicised by both sides of the debate (ranging from central issues of economics, currency, defence, and social justice to relatively marginal issues such as broadcasting rights of $\mathrm{BBC}$ programming and the future of the 'Union Jack' flag), in one sense it is surprising that sporting issues remained on the margins of the referendum campaigns. However, on the other hand, perceptions regarding the marginal impact of sports-related campaign groups and sporting personality endorsements on the referendum campaigns are understandable, given the high levels of public engagement with the constitutional debate and the informed nature of the Scottish electorate who instead concerned themselves with weightier issues such as economic considerations, foreign affairs and defence. Indeed, reflecting upon the potential impact of sporting issues on the outcome of the Scottish independence referendum, Jarvie (2017) concluded that: 
during the Scottish Referendum campaign sport was neither a driver of cultural or political nationalism nor a hotly contested political issue. This is in the sense that it had no real political power in helping either the Yes or No campaign to achieve their political goals or influence Yes or No voters which way to vote. (2017: 219)

Indeed, it appeared that sporting policy issues remained a low priority to the 'Yes Scotland' and 'Better Together' campaigns; nonetheless, the analysis of proindependence political discourse provided above illustrates that the 'Yes' campaign did attempt to harness sporting issues and policies at certain junctures in their political communication strategy. However, the lack of traction of the 'Sport for Yes' campaign groups in comparison to the more successful cultural organisations such as the 'National Collective' illustrate that the forms of cultural nationalism which came to the fore during the campaign tended to be driven by writers, artists, actors and other members of the creative industries rather than sporting personalities. This is exemplified in the relatively low status of the Scottish sportspeople who officially endorsed the 'Sport for Yes' group, with the group failing to initially draw high-profile athletes and players of a sufficient calibre to attract significant media attention for the group. Given this, the impact of any campaigning from sporting figures is highly questionable. Furthermore, it can also be argued that the strength of the relationship between sporting nationalism and political nationalism remains questionable, with the attention of the Scottish electorate instead focused upon wider economic and societal campaign issues, and sport relegated to the margins of the referendum campaigns. Given that other international contexts such as that of Catalonia, the Basque region and Quebec retain strong sub-state political nationalist 
movements, it remains to be seen whether similar limitations are evident with regards to the use of sporting issues as a form of political mobilisation.

Additionally, given the potential implications for the public image and relations of high-profile, actively-competing athletes (Brentin 2016), and the associated pressures placed upon these athletes with regards to sponsorship and funding agreements, any engagement in the polarising political debate surrounding the independence referendum campaign had the potential to backfire. It is therefore unsurprising that the degree of political involvement from professional sportspersons in Scotland in the referendum campaigns was limited in comparison to other sectors, reflecting the limited benefits and significant risks of such interventions. With the prospects of a second referendum on the horizon, the question of Scottish independence becoming increasingly likely following the 'Brexit' vote for the UK to leave the European Union decision (BBC 2016), it will be interesting to assess whether this pattern is replicated if the debate on Scotland's constitutional status is reignited in the future. Further empirical analyses of the nature and impact of nationalist political discourse which utilises sport as a forms of political communications in other international contexts will undoubtedly continue to shed light into the complex interconnection between sport and political nationalism in the future.

\section{References}

Allison, L., 1986. The politics of sport. Manchester: Manchester University Press. 
Allison, L., 1993. The changing context of sporting life. In: L. Allison, ed. The changing politics of sport. Manchester: Manchester University Press, 1-14.

Allison, L., 2000. Sport and nationalism. In: E. Dunning, ed. Handbook of sports studies. London: Sage, 344-355.

Bairner, A., 1994. Football and the idea of Scotland. In: G. Jarvie and G. Walker, eds. Scottish sport in the making of the nation: ninety-minute patriots? Leicester: Leicester University Press, 9-26.

Bairner, A., 1996. Sportive nationalism and nationalist politics: a comparative analysis of Scotland, the Republic of Ireland, and Sweden. Journal of sport and social issues, 20 (3), 314-334.

Bairner, A., 2000. Football. In G. Jarvie and J. Burnett, eds. Sport, Scotland and the Scots. East Linton: Tuckwell, 87-104.

Bairner, A., 2001. Sport, nationalism and globalization: European and North American perspectives. Albany, NY: State University of New York Press.

Bairner, A. and Whigham, S., 2014. Sport and the Scottish diaspora. In M.S. Leith and D. Sim, eds. The modern Scottish diaspora: contemporary debates and perspectives. Edinburgh: Edinburgh University Press, 206-221. 
Barnes, E., 2012. Alex Salmond 'silencing' Scots, says Sir Alex Ferguson. The Scotsman [online], 16 Dec. Available from: http:/www.scotsman.com/news/alexsalmond-silencing-scots-says-sir-alex-ferguson-1-2694386 [Accessed 25 October 2016].

BBC, 2014. Scottish Referendum: Scotland Votes No to Independence. BBC News [Online], 19 September. Available from: http://www.bbc.co.uk/news/uk-scotland29270441 [Accessed 25 October 2016]

BBC, 2015. General Election Results 2015. BBC News [online], 8 May. Available from: http://www.bbc.co.uk/news/election/2015/results [Accessed 25 October 2016]

BBC, 2016. New Scottish independence bill published. BBC News [online], 20 Oct. Available from: http://www.bbc.co.uk/news/uk-scotland-scotland-politics-37708545 [Accessed 25 October 2016].

Beck, P., 1999. Scoring for Britain: international football and international politics, 1900-1939. London: Frank Cass.

Better Together, 2014a. Scotland's football legends unite to say No Thanks to separation [online]. Available from: https://twitter.com/UK_Together/status/ 508243044685336576 [Accessed on 25 October 2016].

Better Together, 2014b. Some of Scotland's greatest rugby legends explain why they have thrown their weight behind a No vote [online]. Available from: 
https://twitter.com/UK_Together/status/511219131652517888 [Accessed on 25 October 2016].

Billig, M., 1995. Banal nationalism. London: Sage.

Blain, N., Boyle, R., and O'Donnell, H., 1993. Sport and national identity in the European media. Leicester: Leicester University Press.

Blommaert, J., 2005. Discourse. Cambridge: Cambridge University Press.

Boyle, D., 2014. David Moyes, Alan Hansen, Ally McCoist and other Scottish heroes say no to independence... And are criticised by fans. The Daily Mail [online], 6 Sep. Available from: http://www.dailymail.co.uk/sport/football/article2746382/David-Moyes-Alan-Hansen-Ally-McCoist-Scottish-heroes-say-noindependence-And-criticised-fans.html\#ixzz4O6VvBg61 [Accessed 25 October 2016].

Boyle, R. and Haynes, R., 2009. Power play: sport, the media and popular culture. 2nd ed. Edinburgh: Edinburgh University Press.

Bradley, J., 1998. Sport, culture, politics and Scottish society: Irish immigrants and the Gaelic Athletic Association. Edinburgh: John Donald.

Bradley, J., 2007. The Gaelic Athletic Association and Irishness in Scotland: history, ethnicity, politics, culture and identity. Edinburgh: Argyll Publishing. 
Brand, J., 1978. The national movement in Scotland. London: Routledge \& Kegan Paul.

Brentin, D., 2016 'Ready for the homeland? Ritual, remembrance and political extremism in Croatian football', Nationalities Papers (Online) 1-17

Buchanan, R., 2014. Scottish independence: Andy Murray backs Yes campaign in eleventh hour decision. The Independent [online], 18 Sep. Available from: http://www.independent.co.uk/news/people/scottish-independence-andy-murraybacks-the-yes-campaign-in-eleventh-hour-decision-9739784.html. [Accessed 25 October 2016].

Casanas Adam, E., 2014. Self-determination and the use of referendums: the case of Scotland. International journal of politics, culture and society, 27, 47-66.

Channel 4 News, 2012. Andy Murray: do sport and politics mix? Channel 4 News [online]. Available from: http://www.channel4.com/news/andy-murray-sport-andpolitics-collide. [Accessed 25 October 2016].

Conversi, D., 2000. The Basques, the Catalans and Spain: alternative routes to nationalist mobilisation. Reno, NV: University of Nevada Press.

Crawford, J., 2013. The politics of anti-sectarianism. In: J. Flint and J. Kelly, eds. Bigotry, football and Scotland. Edinburgh: Edinburgh University Press, 180-193. 
Daily Record, 2013a. Independence will make life harder for Scottish athletes says Sir Chris Hoy'. Daily Record [online], 28 May. Available at: http://www.dailyrecord.co.uk/sport/other-sports/chris-hoy-warns-independencescotland-1917594. [Accessed 25 October 2016].

Daily Record, 2013b. Sir Chris Hoy attacked on internet forums over comments he made about Scottish independence. Daily Record [online], 29 May. Available at: http://www.dailyrecord.co.uk/news/politics/sir-chris-hoy-attacked-internet-1919864. [Accessed 25 October 2016].

Dalle Mulle, E., 2016. New trends in justifications for national self-determination: evidence from Scotland and Flanders. Ethnopolitics, 15 (2), 211-229.

Dixon, K., 1996. Notes from the underground: a discussion of cultural politics in contemporary Scotland, Etudes ecossaises, 3, 117-128.

Duke, V. and Crolley, L., 1996. Football, nationality, and the state. Harlow: Longman.

Edensor, T., 2002. National identity, popular culture and everyday life. Oxford: Berg.

Fairclough, N., 2015. Language and power. 3rd ed. London: Routledge. 
Fairclough, N. and Wodak, R., 1997. Critical discourse analysis. In: T. van Dijk, ed. Introduction to discourse studies, London: Sage, 258-284.

Fairclough, I. and Fairclough, N., 2012. Political discourse analysis: a method for advanced students. London: Routledge.

Flint, J. and Kelly, J., 2013. Football and bigotry in Scotland. In: J. Flint and J. Kelly, eds. Bigotry, football and Scotland. Edinburgh: Edinburgh University Press, $3-18$

Goig, R.L., 2008. Identity, nation-state and football in Spain: the evolution of nationalist feelings in Spanish football. Soccer and society, 9 (1), 56-63.

The Guardian, 2014. 'JK Rowling donates £1 million to Scotland's antiindependence campaign', The Guardian $11^{\text {th }}$ June [Online] Available on: https://www.theguardian.com/books/2014/jun/11/jk-rowling-donates-scotlandanti-independence-campaign (Accessed 26th October 2016)

The Guardian, 2014 'Celebrities' open letter to Scotland - full text and list of signatories', The Guardian $7^{\text {th }}$ August $\quad$ [Online] Available on: $\quad$ https://www.theguardian.com/politics/2014/aug/07/celebrities-open-letterscotland-independence-full-text (Accessed 26th October 2016)

Guibernau, M., 2000. Nationalism and intellectuals in nations without states: the Catalan case. Political studies, 48 (5), 989-1005. 
Guttmann, A., 1998. The 'Nazi Olympics' and the American boycott controversy. In: P. Arnaud and J. Riordan, eds. Sport and international politics: the impact of fascism and communism on sport, London: E \& FN Spon, 31-50.

Hargreaves, J., 2000. Freedom for Catalonia? Catalan nationalism, Spanish identity and the Barcelona Olympic Games. Cambridge: Cambridge University Press.

Harvie, C., 1994. Sport and the Scottish state. In: G. Jarvie and G. Walker, eds. Scottish sport in the making of the nation: ninety-minute patriots? Leicester: Leicester University Press, 43-57.

The Herald, 2014. Silver medallist Lynsey Sharp: FM's being unfair to No-voting Scots with his Team Scotland label, The Herald [online], 10 Sep. Available from: http://www.heraldscotland.com/news/13179296.Silver_medallist_Lynsey_Sharp_F M_s_being_unfair_to_No_voting_Scots_with_his_Team_Scotland_label/[Accessed 25 October 2016].

Hill, C.R., 1993. The politics of the Olympic movement. In: L. Allison, ed. The changing politics of sport. Manchester: Manchester University Press, 84-104.

Hobsbawm, E., 1991. Nations and nationalism since 1780: programme, myth, reality. Cambridge: Cambridge University Press.

Holt, R., 1989. Sport and the British: a modern history. Oxford: Oxford University Press. 
Holt, R., 1998. The Foreign Office and the Football Association: British sport and appeasement, 1935-1938. In: P. Arnaud and J. Riordan, eds. Sport and international politics: the impact of fascism and communism on sport, London: E \& FN Spon, 5166.

Horne, J. and Manzenreiter, W., 2006. An introduction to the sociology of sports mega-events. The sociological review, 54: 1-24.

Houlihan, B., 1994. Sport and international politics. London: Harvester Wheatsheaf.

Houlihan, B., 2000. Politics and sport. In: E. Dunning, ed. Handbook of sports studies. London: Sage, 213-227.

Hutchinson, J., 2001. Nations and Culture. In: M. Guibernau, M. and J. Hutchinson, eds. Understanding nationalism. Cambridge: Polity, 74-96.

Jarvie, G., 1993. Sport, nationalism and cultural identity. In: L. Allison, ed. The changing politics of sport. Manchester: Manchester University Press, 58-83.

Jarvie, G., 2017. Sport, the 2014 Commonwealth Games and the Scottish referendum. In: A. Bairner, J. Kelly and J.W. Lee, eds. The Routledge handbook of sport and politics. London: Routledge, 209-221.

Jarvie, G. and Walker, G., 1994. Ninety-minute patriots? Scottish sport in the making of the nation. In: G. Jarvie and G. Walker, eds. Scottish sport in the making of the nation: ninety-minute patriots? Leicester: Leicester University Press, 9-26. 
Keating, M., 2012. Rethinking sovereignty. Independence-lite, devolution-max and national accommodation. Revista d'estudis autonomics i federals, 16, 9-29.

Kedourie, E., 1960. Nationalism. London: Hutchinson.

Kellas, J.G., 1998. The politics of nationalism and ethnicity, 2nd ed. Basingstoke: Macmillan.

Kiely, R., Bechhofer, F., and McCrone, D., 2005. Birth, blood and belonging: identity claims in post-devolution Scotland. The sociological review, 53 (1), 150171.

Kohn, H., 1944. The idea of nationalism. New York: Macmillan.

Kowalski, R., 2004. 'Cry for us, Argentina': Sport and national identity in late twentieth-century Scotland. In: A. Smith and D. Porter, eds. Sport and national identity in the post-war world. London: Routledge, 69-87.

Lafferty, S., 2014. Stars of sport say Yes to an independent Scotland, Yes Scotland [online]. Available from: http://www.yesscotland.net/news/stars-sport-say-yesindependent-scotland [Accessed on 14 July 2014].

Lecours, A., 2012. Sub-state nationalism in the western world: explaining continued appeal. Ethnopolitics, 11 (3), 268-286. 
Leith, M.S. and Soule, D.P.J., 2011. Political discourse and national identity in Scotland. Edinburgh: Edinburgh University Press.

Lynch, P., 2009. From social democracy back to no ideology? The Scottish National Party and ideological change in a multi-level electoral setting. Regional \& federal studies, 19 (4-5), 619-637.

Maclennan, H.D., 2000. Shinty. In: G. Jarvie and J. Burnett, eds. Sport, Scotland and the Scots. East Linton: Tuckwell, 211-228.

Maguire, J., et al., 2002. Sport worlds: a sociological perspective. Leeds: Human Kinetics.

Mandell, R., 1971. The Nazi Olympics. New York: Macmillan.

McCartney, G., Hanlon, P., and Bond, L. (2012) How will the 2014 Commonwealth Games impact on Glasgow's health, and how will we know?, Evaluation, 19 (1): 2439.

McCartney, G., Palmer, S., Winterbottom, J., Jones, R., Kendall, R., and Booker, D. (2010) A health impact assessment of the 2014 Commonwealth Games in Glasgow, Public Health, 124: 444-451. 
McCrone, D., 1992. Understanding Scotland: The sociology of a stateless nation. London: Routledge.

McCrone, D., and Bechhofer, F., 2010. Claiming national identity. Ethnic and racial studies, 33 (6), 921-948.

Moorhouse, H.F., 1987. Scotland against England: Football and popular culture. International journal of the history of sport, 4 (2), 189-202.

Muda, M., 1998. The significance of Commonwealth Games in Malaysia's foreign policy. The round table, 346, 211-226.

Munoz, F., 2006. Olympic urbanism and Olympic Villages: planning strategies in Olympic host cities, London 1908 to London 2012. The sociological review, 54: $175-187$.

Mycock, A., 2012. SNP, identity and citizenship: re-imagining state and nation. National identities, 14 (1), 53-69.

Nairn, T., 1977. The break-up of Britain. London: New Left Books.

National Collective, 2014 'Over 1300 artists sign letter in support of Yes vote', National Collective $\quad 7^{\text {th }} \quad$ September $\quad[$ Online $] \quad$ Available on: $\underline{\text { http://nationalcollective.com/2014/09/07/over-1300-artists-sign-letter-in-support- }}$ of-yes-vote/ (Accessed 25 October 2016) 
Newby, A., 2009. 'In building a nation few better examples can be found': Norden and the Scottish Parliament. Scandinavian journal of history, 34 (3), 307-329.

Palmer, C., 2013. Global sports policy. London: Sage.

Pittock, M., 2008. The road to independence? Scotland since the sixties. London: Reaktion Books.

Pittock, M., 2012. Scottish sovereignty and the union of 1707: then and now. National identities, 14 (1), 11-21.

Polley, M., 2004. Sport and national identity in contemporary England. In: A. Smith and D. Porter, eds. Sport and national identity in the post-war world. London: Routledge, 10-30.

Riordan, J., 1998. The sports policy of the Soviet Union, 1917-1941. In: P. Arnaud and J. Riordan, eds. Sport and international politics: the impact of fascism and communism on sport. London: E \& FN Spon, 67-78.

Robertson, G., 2014. Andy Murray troll says 'wish you had been killed at Dunblane' after Scottish Yes vote tweet, The Mirror [online], 18 Sep. Available from: http://www.mirror.co.uk/news/uk-news/andy-murray-troll-says-wish-4280737 [Accessed 25 October 2016]. 
Roden, A., 2013. Cycling hero Sir Chris Hoy branded a 'bigot' by Scottish nationalists in online campaign of abuse after raising concerns about independence, Daily Mail, [online] 29 May. Available at: http://www.dailymail.co.uk/news/article2332868/Cycling-hero-Sir-Chris-Hoy-branded-bigot-Scottish-nationalists-onlinecampaign-abuse-raising-concerns-independence.html [Accessed 25 October 2016].

Rosie, M., 2013. Outside the hothouse: perspectives beyond the Old Firm. In: J. Flint and J. Kelly, eds. Bigotry, football and Scotland. Edinburgh: Edinburgh University Press, 19-33.

Scottish Government, 2013. Scotland's future: your guide to an independent Scotland. Edinburgh: Scottish $\quad$ Government. $\quad$ Available from:http://www.gov.scot/Publications/ 2013/11/9348/downloads [Accessed 25 October 2016].

Scottish Government, 2014. Working Group on Scottish Sport - Scottish Government response to report. Press release, 9th May 2014.

Scottish Government, 2015. Sport - major events [online]. Available from: http://www.gov.scot/Topics/ArtsCultureSport/Sport/MajorEvents. [Accessed 25 October 2016].

Scottish National Party, 2014a. 2014 Tourism - hit by Westminster's Air Travel Tax [online]. Available from: http://www.snp.org/media-centre/news/2014/jan/2014tourism-hit-westminsters-air-travel-tax [Accessed on 25 October 2016]. 
Scottish National Party, 2014b. No vote would see APD continue to blight Scotland [online]. Available from: http://www.snp.org/media-centre/news/2014/jul/no-votewould-see-apd-continue-blight-scotland [Accessed on 25 October 2016].

Shipman, T., 2014. Murray tells Salmond to put his saltire away. The Sunday Times [online]. Available from: http://www.thesundaytimes.co.uk/sto/news/uk_news/ scotland/article1420257.ece. [Accessed 29 June 2015].

Shobe, H., 2008a. Football and the politics of place: Football Club Barcelona and Catalonia, 1975-2005. Journal of cultural geography, 25 (1), 87-105.

Shobe, H., 2008b. Place, identity and football: Catalonia, catalanisme and Football Club Barcelona, 1899-1975. National identities, 10 (3), 329-343.

Smith, A.D., 1991. National identity. London: Penguin

Smith, A.D., 2010. Nationalism. 2nd ed. Cambridge: Polity Press.

Smith, A. and Porter, D., 2004. Introduction. In: A. Smith and D. Porter, eds. Sport and national identity in the post-war world. London: Routledge, 1-9.

Sport for Yes, n.d.@SportforYes Twitter homepage [online]. Available from: https://twitter.com/SportforYes. [Accessed on 25 October 2016]. 
Tomlinson, J., 2014. Imagining the economic nation: the Scottish case. The political quarterly, 85 (2), 170-177.

Vaczi, M., 2015a. Soccer, culture and society in Spain: an ethnography of Basque fandom. London: Routledge.

Vaczi, M., 2015b. "The Spanish Fury": a political geography of soccer in Spain. International review for the sociology of sport, 50 (2), 196-210.

Vaczi, M., 2017. Their skin in the game: the Basques, the Catalans and the 'body politic' of the Spanish national football team. In: A. Bairner, J. Kelly and J.W. Lee, eds. The Routledge handbook of sport and politics. London: Routledge, 174-186.

Waiton, S., 2013. The new sectarians. In: J. Flint and J. Kelly, eds. Bigotry, football and Scotland. Edinburgh: Edinburgh University Press, 99-114.

Whigham, S., 2014. 'Anyone but England'? Exploring anti-English sentiment as part of Scottish national identity in sport. International review for the sociology of sport. $49(2), 152-174$.

Working Group on Scottish Sport and Scottish Government, 2013. Working Group on Scottish Sport interim statement. Edinburgh: Scottish Government. Available from: http://www.scotland.gov.uk/Resource/0043/00437896.pdf. [Accessed 25 October 2016]. 
Working Group on Scottish Sport and Scottish Government, 2014. Working Group on Scottish Sport: The continuing development of Scottish sport - including the impact of independence. Edinburgh: Scottish Government. Available from: http://www.scotland.gov.uk/Resource/0044/00449792.pdf. [Accessed 25 October 2016].

Yes Scotland., 2014. Andy Murray declares for Yes - and brother Jamie follows up with a late Yes volley, Yes Scotland [online]. Available from: http://us4.campaignarchive2.com/?u=3d8f589fda4fb7526a70254d4\&id=3aae90999a [Accessed on 25 October 2016]. 